NBER WORKING PAPER SERIES

\title{
UNEMPLOYMENT RISK AND COMPENSATING DIFFERENTIALS \\ IN LATE-NINETEENTH CENTURY \\ NEW JERSEY MANUFACTURING
}

\author{
Susan Averett \\ Howard Bodenhorn \\ Justas Staisiunas \\ Working Paper 9977 \\ http://www.nber.org/papers/w9977 \\ NATIONAL BUREAU OF ECONOMIC RESEARCH \\ 1050 Massachusetts Avenue \\ Cambridge, MA 02138 \\ September 2003
}

This research was funded, in part, by the Excel Scholars program at Lafayette College. We thank Shawn Kantor for comments on an earlier version. The views expressed herein are those of the authors and are not necessarily those of the National Bureau of Economic Research.

C2003 by Susan Averett, Howard Bodenhorn, and Justas Staisiunas All rights reserved. Short sections of text, not to exceed two paragraphs, may be quoted without explicit permission provided that full credit, including $\odot$ notice, is given to the source. 
Unemployment Risk and Compensating Differential in

Late-Nineteenth Century New Jersey Manufacturing

Susan Averett, Howard Bodenhorn, and Justas Staisiunas

NBER Working Paper No. 9977

September 2003

JEL No. N31, J33, J65

\begin{abstract}
$\underline{\text { ABSTRACT }}$
In this paper we test for the existence of compensating differentials for unemployment risk in an era before unemployment insurance. Using information gathered from manufacturing worker surveys conducted during the 1880s in New Jersey, we find that workers who faced higher probabilities of predictable unemployment spells received a small compensating differential. Low-skill laborers and operatives were partially compensated for unemployment risks; skilled craftsmen were not. Although workers were not fully compensated for the unemployment risks they accepted, the results are of interest because most previous writers, dating back to Adam Smith, doubted the existence of compensating differentials in manufacturing. Differentials are typically believed to arise in employments with pronounced seasonal components, such as agriculture and construction.

Susan Averett

Department of Economics

Lafayette College

Easton, PA 18042

averetts@lafayette.edu
\end{abstract}

Howard Bodenhorn

Department of Economics

Lafayette College

Easton, PA 18042

and NBER

bodenhoh@lafayette.edu

Justas Staisiunas

Department of Economics

Lafayette College

Easton, PA 18042

staisiuj@lafayette.edu 


\section{Unemployment Risk and Compensating Differentials in Late-Nineteenth Century New Jersey Manufacturing}

As with so many questions that still engage the attention of modern economists, Adam Smith observed and commented on the phenomenon of compensating wage differentials. Smith $(1776 / 1909$, Chapter X) observed that, ceteris paribus, wages were higher the more disagreeable the work and the greater the inconstancy of work. He wrote:

In the greater part of manufactures, a journeyman may be pretty sure of employment almost every day in the year that he is able to work. A mason or bricklayer, on the contrary, can work neither in hard frost nor in foul weather, and his employment at all other times depends upon the occasional call of his customers. He is liable, in consequence, to be frequently without any. What he earns, therefore, while he is employed, must not only maintain him while he is idle, but make him some compensation for those anxious and desponding moments which the thought of so precarious a situation must sometimes occasion (Smith 1776/1909, p. 109).

Smith's insight into compensating differentials is now so widely accepted that the typical undergraduate labor economics textbook provides an extended discussion of the subject, placing it within formal models of utility maximization and reviewing empirical work broadly consistent with it (see, for example, Ehrenberg and Smith 2000).

Given that Smith's hypothesis is now more than 200 years old, we would expect to find a large body of empirical work bearing on it. Such is not the case. There are a number of studies using historical or modern data testing the relationship between job disamenities and compensation, but less than a handful of extent historical studies explicitly test whether workers were compensated for ex ante expectations of higher than average unemployment risk. Fishback 
(1998) reviews historical studies addressing the compensating differentials for job disamenities hypothesis, which find that in the late-nineteenth century railroad workers, coal miners, New Jersey child workers, as well as laborers in California, Indiana, Maine and Kansas were all compensated, to varying degrees, for on-the-job accident risks. In a pair of studies, Williamson (1982) and Brown (1990) even uncover a nineteenth-century urban wage premium that they attribute, in part, to compensation for unsanitary and generally disagreeable off-the-job urban living conditions. Thus, unfettered nineteenth century labor markets provided some measure of insurance against accident risks and other workplace disamenities by offering workers wage premia in return for their acceptance of risk and disagreeableness, but the premia generally did not fully offset losses in income (Fishback and Kantor 1992, p. 845).

Similarly, the risk of involuntary idleness was a very real problem for workers in the latenineteenth century and, in a well-functioning labor market without unemployment insurance, employers should have offered wage premia to compensate workers for accepting a higher risk of layoff (Keyssar 1986; Fishback and Kantor 1992, p. 830). Using information on laborers employed in agriculture, construction, and railroading in Michigan in the mid-1890s, Hatton and Williamson (1991) find that laborers received substantial wage premia in return for higher $e x$ ante probabilities of extended periods of involuntary unemployment. They contend that this is fully consistent with Smith's hypothesis because it concerns anticipated unemployment, which is why he expected to observe differentials in industries with strong seasonal components like construction and agriculture. While not all workers would be laid off in the slack period, each worker faced a positive probability of being involuntarily idled. Thus, it is in jobs where the likelihood of unemployment was relatively high that we would expect to find ex ante wage bargains which compensate for that risk. But Williamson and Hatton (1991, p.608), like Smith, 
doubt the existence of comparable premia for manufacturing laborers because bouts of involuntary idleness in manufacturing tended to be the product of random cyclical rather than recurrent seasonal movements.

Hatton and Williamson reach this conclusion because they, like Smith, accept that most manufacturing enterprises operated continuously, but Keyssar (1986, p. 36) observed that even in manufacturing steady work was the exception, not the rule. Extracts of interviews with manufacturing workers in New Jersey reveal periods of extended and anticipated downtime comparable to those experienced by workers in agriculture and construction. A glass blower in Millville, New Jersey, said that his place of employment typically shut down in July and August, yet glass blowers "actually made more money working ten months than they could if the factories were in operation during the whole year" (New Jersey 1885, p.238). A silk worker in Paterson described a pattern of slack work between October and March, a period with mass layoffs between May and August, with a 'rush' of work between August and October. Recurring patterns of periodic seasonal layoffs in manufacturing were also detailed by an iron worker in Trenton, a hatter in Orange, a carriage maker in Hackettstown, a printer in Trenton, and an upholsterer in Rahway, among others. Extended bouts of anticipated unemployment occurred in manufacturing, though, perhaps, not as common as in agriculture and construction.

Using establishment-level data, Atack, Bateman and Margo (2002) find that seasonal unemployment was common in many industries. They report that at 60 percent of manufacturing establishments canvassed in the 1880 census a worker would have been idled only if he or she quit, was fired, or was selectively laid off during a cyclical downturn. This left employees at the other 40 percent of manufacturing establishments facing often extended periods of idleness because the enterprise operated for only part of the year. After controlling for other factors, 
Atack, Bateman and Margo (2002, pp. 805-806) report that workers in part-year establishments received monthly wages about 12 percent higher than workers at year-round establishments. Similarly, Atack, Bateman and Margo (2003, p. 188) report a small per diem compensating differential for day laborers compared to workers paid by the week or month. Both results are consistent with Fishback and Kantor's (1992) findings that workers in California, Indiana, Kansas and Maine all received wage premia in return for higher layoff risks, but that the ex ante compensation was generally insufficient to fully compensate for ex post loss in earnings.

This paper contributes to the literature by investigating whether manufacturing workers in New Jersey in the mid-1880s received compensating differentials for layoff risk. We follow Fishback and Kantor (1992) in that we employ quantitative data supplied in the published surveys conducted by a state labor bureau to determine if manufacturing workers of different skill levels employed in a broad range of industries were compensated for bouts of involuntary unemployment. Our results are equivocal. On one hand, we find that the expectation of missing some work led to higher wages among low-skill laborers and factory operatives, but not for skilled craftsmen. One the other, we find that the actual compensation for each anticipated day of involuntary idleness was very small across all three classes of workers, and was probably insufficient to fully compensate for the unemployment risks they faced.

\section{New Jersey's Industry Surveys}

It is well known that in the period between the Civil War and the First World War, the United States shifted from an industrializing to an industrialized economy, from an urbanizing to an urbanized one. New Jersey not only followed the national trend in these changes, in many ways it was one of the leaders. In 1850, New Jersey had just over 489,000 inhabitants, with 66 
residents per square mile. By 1890 , the state was home to nearly 1.5 million inhabitants and had become the nation's third most densely populated state, behind Rhode Island and Massachusetts, with 194 residents per square mile. In 1870, New Jersey boasted three of the nation's 50-largest cities (Jersey City, Newark, and Paterson). In 1890, Camden and Trenton were added to the list. ${ }^{1}$

As the state became more urbanized, workers shifted from agriculture to manufacturing and commercial employments. In 1870, 21.3 percent of gainfully employed workers 10 years or older were employed in agriculture; by 1890 , just 13.1 percent were. Over the same interval, the proportion of the labor force employed in manufacturing, trade and transport increased from 50.5 to 60.3 percent. Although the foreign-born made up an increasing percentage of the population (12.2 percent in 1850 to nearly 23 percent in 1890 ), the proportion of foreign-born to all manufacturing workers remained constant at about 36 percent between 1870 and 1890 .

One consequence of these changes was that unemployment and immigration became worthy of political discourse because workers made these issues the politicians' business. Indeed, as Keyssar (1986, p. 40) notes, it was during this era that the term 'unemployment' first entered the lexicon, and the business depressions of the 1870s and 1890s brought the problem to the top of the political agenda. In an interview conducted by the Massachusetts Bureau of Statistics of Labor in the 1870s, one worker reported that "I earn three hundred dollars less than I ought to for the reason that I only have employment about two-thirds of the time ... I consider myself underpaid because I am unemployed" (quoted in Keyssar 1986, p. 20). This worker's attitude reflected a spreading sentiment that employees were entitled to safe, healthy, fairly recompensed, year-round employment. Industrialization sped the pace and extended the routinization of work, and workers increasingly believed that an equitable tradeoff involved

\footnotetext{
${ }^{1}$ Statistics of population and employment are drawn from U.S. Census Office (1872), U.S. Department of the Interior (1883), and U.S. Department of the Interior (1895).
} 
greater safety and regularity of work. Fishback and Kantor (1992) note that many Progressive Era reformers, including some then-prominent economists, took up the workers' cause, publicizing unsafe, unhealthy, and irregular employments. The reformers pushed for and won passage of various regulations, including several social insurance schemes that compensated workers or their families for on-the-job injuries, job-related fatalities, and bouts of unemployment.

One of the reforms won by progressive reformers was the establishment of state-level labor bureaus, whose charge was to investigate and report on the conditions of employment in various trades. New Jersey's Bureau of Statistics of Labor and Industries investigated working conditions in manufacturing establishments throughout the state and began publishing annual reports in 1877 . In the late 1870 s and early 1880 s, the bureau published reports on the general conditions of employment in the state, without much in the way of supporting evidence. Between 1883 and 1886, however, the Bureau published, in tabular form, detailed quantitative information for individuals interviewed as part of the Bureau's inspections. While the questions varied slightly from year to year, the Bureau reported the broad industry in which the worker was employed (glass factory, silk weaving, cotton mill, etc.); the city or town in which the factory was located; a reasonably detailed job title (glass blower, power loom weaver, warper, etc.); the number of hours in a typical work day; earnings per day, week, or month; annual income; income accruing to the worker's household from other sources; family size; the number of days lost from illness, an inability to find work, or other causes; the estimated cost of living; and whether the family had added to its savings in the past year.

Combining data from the Bureau's sixth (1883), seventh (1884), eighth (1885) and ninth (1886) annual reports, we construct a sample of 1,647 unskilled laborers, 466 semi-skilled 
operatives, and 339 skilled craftsmen employed in manufacturing enterprises. We also have information on a small number of clerical and professional persons who are excluded from the analysis. We divide the data into three separate skill-level samples because, as Hatton and Williamson (1991, p. 607) note, the existence of a compensating differential is likely to be obscured if we attempt to identify it across skill groups. A significant contribution of our paper, in this regard, is that it offers the first insight into potential differences in layoff probabilities and compensating differentials between skilled, semi-skilled, and unskilled workers. This is an important issue because there is a general belief that skilled employees are less likely to suffer repeated bouts of unemployment because it is more costly for firms to replace them when the economy rebounds. Indeed, Hatton and Williamson (1991, p. 607) write: "it is widely acknowledged [that] skilled workers tend to suffer less unemployment (whether their skills are general or firm specific) than the unskilled." Yet in his careful study, Keyssar (1986, p. 55) cites contemporaries who believed that employers were no more likely to retain skilled than unskilled workers. Our study brings some data to bear directly on this issue. We find that craftsmen were, in fact, less likely than unskilled laborers to experience a period of involuntary idleness, but many experienced it nonetheless.

As rich as our data set is, it has shortcomings. We cannot control for age, education, or nativity because the New Jersey labor bureau did not systematically collect or report this information in their detailed tables. A lack of information on these variables should not pose a serious obstacle to testing for compensating differentials because Keyssar (1986) contends that immigrant workers in Massachusetts did not experience a sharply higher incidence of unemployment than native-born workers. After controlling for other factors, Hatton and Williamson (1991, pp. 613-617) find only small and statistically insignificant effects for 
German, British and other immigrants. Like us, Fishback and Kantor (1992) do not control for nativity.

Keyssar (1986, p. 92, table 4.6) also argues that age was not a determining factor when Massachusetts' employers engaged in selective layoffs. ${ }^{2}$ Workers under 20 faced a 37 percent probability of layoff, compared to a slightly less than 30 percent probability across all other decadal age cohorts between 20 and 80 years. However, Hatton and Williamson find that the incidence of unemployment for farm workers increased up to about age 55, but found no statistically significant relationship for railroad workers. Fishback and Kantor find that $(\log )$ wages rose up to about age 37. Although it would be better if we could better control for each worker's personal characteristics, we take comfort in Hatton and Williamson's (1991, p. 613) conclusion that the data support Keyssar's 'lottery' view of unemployment in that personal characteristics explain little of the observed incidence of unemployment.

Finally, Smith's compensating differential hypothesis is a theory of long-run tradeoffs and we are given only short-run data with which to test it. Because we have only four years of data, it is possible that the wage differentials we observe reflect short-term disequilibria or cyclical components rather than long-run relationships. Indeed, the NBER dates the nearest business cycle peak in March 1882 with the trough in 1885, so that our data is drawn partly from an economic downturn and partly from a recovery. But the recession of the early 1880 s was mild compared to the substantial and prolonged downturns experienced in 1870s and the 1890s. If the recession generated substantial unanticipated unemployment, it will be more difficult to extract evidence of a compensating differential from the data. Thus, our estimates provide a relatively strong test of the hypothesis because the results will be biased against finding compensating

\footnotetext{
${ }^{2}$ Our data includes information on family size, which may be (nonlinearly) correlated with age. Because it may be correlated with a worker's unobserved age, the family size coefficient reported below may be biased upward.
} 
differentials. Moreover, to the extent that there was substantial unanticipated unemployment any differential we find is likely to represent a lower-bound estimate of the long-run equilibrium differential.

Our empirical analysis rests on estimating log wage models as a function of involuntary unemployment controlling for various worker and job characteristics. The data allow us to differentiate between bouts of idleness caused by unemployment (reported as an inability to find work), illness, and other causes. Involuntary unemployment is measured as lost work due to an inability to find work. Thus, we use these terms interchangeably. In the New Jersey surveys, earnings were reported daily, weekly, or monthly. Fishback and Kantor (1992) note that those paid by the day might be more susceptible to layoff risk and they find empirical evidence from California that confirms this hypothesis. We also find this. ${ }^{3}$ The annual surveys also report the length of the typical workday in hours. We use this information to create an hourly earnings variable. $^{4}$ We necessarily delete those few observations where no information on earnings was recorded.

We combine the New Jersey labor bureau data by county with the data from 1880 Census of Manufacturing in New Jersey. The census data contains information on population, number of manufacturing establishments, total capital invested in manufacturing, as well as total wages in manufacturing, each variable categorized by county. We use these Census data to create variables for the county level capital-labor ratio and the number of manufacturing

\footnotetext{
${ }^{3}$ In our data, information on earnings was collected in the fashion of earnings daily, weekly, or monthly. Because many workers reported more than one time period, we classified those as paid daily if they reported daily pay either alone or in conjunction with weekly or monthly. Similarly, if they did not report daily pay but reported weekly pay we record them as paid weekly. No workers reported only monthly pay.

${ }^{4}$ Participants provided answers to one, two or all three of the above categories. To have a uniform measure of earnings we converted all earnings into the form of daily earnings (daily earnings $=$ weekly earnings $/ 6$ or monthly
} 
establishments. As we noted previously, we categorize each individual by his or her occupation into one of four groups: laborers, operatives, craftsmen, and clerical/ service/ professional (the latter group is excluded because it contains a very small number of observations). However, since there is considerable heterogeneity in the job descriptions under these broad categories, we assign Duncan's Socioeconomic Index to each participant, with laborers receiving the lowest, and professionals the highest values of the index (Reiss 1961).

We also control for any systematic regional differences in employment separate from manufacturing establishments by classifying each observation into one of four regional categories: Northeast (Passaic, Hudson, Bergen, Union, Essex, and Middlesex counties), Northwest (Sussex, Warren, Morris, Hunterdon, and Mercer counties), Central (Monmouth, Ocean, Burlington, and Camden counties), and South (Salem, Cumberland, and Gloucester counties). ${ }^{5}$ Finally, we deleted 10 hourly wage outliers. ${ }^{6}$

\section{The Incidence of Unemployment in New Jersey, 1883-1886}

Before we explore the correlates of unemployment and whether workers were compensated for unemployment risk, it might be useful to consider the pattern of lost time among New Jersey manufacturing workers in the mid-1880s. Statistics reported in Table 1 demonstrate that extended periods of involuntary idleness were common in New Jersey manufacturing establishments. Nearly 85 percent of laborers missed one or more days of work for any reason and fully one-half of all laborers experienced a period of unemployment, and lost an average of

earnings / 26). Fishback and Kantor also create hourly earnings in this way. We then divided this by daily hours worked to create a daily earnings variable. We convert all earnings to 1886 dollars.

${ }^{5}$ Note, that there were no observations in our data set from Atlantic, Cape May and Somerset counties. A small number of people reported either no location, or reported a town that could not be matched with a county. Such observations we deleted from the sample.

${ }^{6}$ We determined these observations were outliers using the HADI procedure in STATA. 
27 days per year. Seventy-six percent of operatives missed days of work for any reason and nearly 40 percent experienced a period of involuntary idleness, and lost an average of 24 days. Finally, consistent with prior expectations, just 37 percent of skilled craftsmen experienced a period of unemployment due to inability to find work; they lost an average of 21 days. Skilled workers, as Smith believed, were less likely to experience a period of involuntary unemployment, but many still experienced it.

Unemployment appears to be unexpectedly pervasive among manufacturing workers interviewed by the New Jersey labor bureau, but they are fully consistent with the experience of Michigan farm workers, railway laborers, and construction workers in the 1890s. Indeed, in these highly seasonal employments, the average worker experienced between 3.5 and 3.9 months of unemployment (Hatton and Williamson 1991, p. 610), which is about four to five times longer than bouts of unemployment experienced by the typical New Jersey manufacturing worker. A similar pattern emerges when we compare statistics of unemployment in New Jersey with those in Massachusetts in the mid-1880s. While Keyssar (1986, p. 51) does not separate his sample by skill level, it appears that workers in Massachusetts were somewhat less likely to experience an unemployment spell (30 percent), but when they did the spell lasted much longer (4.2 months). The full sample statistics for our New Jersey workers reveals that 50 percent experienced an unemployment spell, but lost less than two months (57 days) from all causes. Differences in the probability of unemployment in New Jersey and Massachusetts are probably more apparent than real because Keyssar includes several occupations with high levels of job attachment in his statistics, including merchants, government employees, salesmen, and bookkeepers, clerks, and office boys. 
Differences in unemployment duration are less easily explained. Even when Keyssar (1986, table A.1) reports statistics separately by broad industry classifications, we still find substantially longer periods of idleness in Massachusetts than in New Jersey in most industries. Among glass workers in Massachusetts, for example, 46.5 percent experienced a period of unemployment in 1885 , compared to 56.1 percent of glass workers in New Jersey. But the average glass worker in Massachusetts was unemployed for 87 days compared to just 32 days in New Jersey. The differences were even more striking among shoemakers. In Massachusetts, the average shoemaker lost 117 days to unemployment, while the average New Jersey shoemaker lost 26 days. Among laborers not otherwise classified, 61.5 percent of unskilled workers in Massachusetts experienced a layoff, whereas 43.3 percent of New Jersey workers did. The average unskilled laborer in New Jersey also experienced just 35 days of unemployment compared to 120 days in Massachusetts. James (1995) also found that, during the Gilded Age, workers in Massachusetts were more likely to experience one long spell of unemployment rather than several short ones. Extracts from interviews with workers suggest that New Jersey workers experienced a single, comparatively brief period of unemployment.

Evidence on unemployment from Maryland (1886) also suggests that industrial workers in Gilded Age New Jersey experienced unusually brief unemployment spells. For the dozen or so occupations that we could match, we found that Maryland workers' unemployment spells were significantly longer. In the building trades, for example, Maryland workers reported an average of 146 days; in New Jersey just 77 days. Maryland's carriage makers were involuntarily unemployed more than twice as many days (141 days) as carriage makers in New Jersey (62 days). Similarly, Marylanders employed as cotton mill operatives, potters, printers, ship builders, as well as those in glass factories, in the leather trades, and in railroading typically 
experienced more than twice as many days of involuntary unemployment as comparable workers in New Jersey. Explaining these substantial interstate differences in layoff probability and duration awaits further research, but it is notable that many New Jersey manufacturing workers seemingly experienced fewer and shorter periods of forced idleness than workers in Maryland and Massachusetts. Because New Jersey workers experienced rather brief periods of involuntary unemployment, on average, the statistical results will be biased against finding a substantial compensating differential. Workers who experienced relatively brief bouts of involuntary unemployment may have demanded, or received, little compensation for their smaller relative unemployment risks.

In Table 1, we also present several other descriptive statistics. We show the average wage earned in constant 1886 dollars, the average hours worked per day and average SEI code. The ten-hour workday was common to all three groups. On average craftsmen and operatives earned slightly more per hour than laborers, but the skill differential was modest. The SEI code rises as you move from laborer to craftsmen, as expected. We now turn to the determinants of unemployment in New Jersey manufacturing, and then turn to a more formal test of the compensating differential hypothesis.

\section{Determinants of Unemployment in New Jersey Manufacturing, 1883-1886}

Table 2 presents results from models that attempt to uncover the correlates of involuntary layoffs in late nineteenth century New Jersey. We follow specifications similar to those used by Hatton and Williamson (1991) and estimate the probability of missing some work due to inability to find work using a probit model; we also estimate the number of days of work missed due to inability to find work using a tobit specification. The tobit specification is used to account 
for the censoring of the days lost variable. To facilitate interpretation, Table 2 presents partial derivatives from the probit and tobit models calculated at the sample means of the independent variables. Separate regressions are estimated for each of the three broad occupation categories.

The results of these models largely correspond to the hypotheses put forth by both Keyssar (1986) and Hatton and Williamson (1991)--there is considerable evidence that unskilled workers were more likely to experience involuntary unemployment. For both laborers and craftsmen, those who are paid weekly rather than daily are less likely to experience involuntary unemployment. Interestingly, the opposite is true for operatives paid weekly, who were more likely to be laid off. The evidence at hand provides few clues to interpret this apparently anomalous result, and we have no plausible explanation for it. The SEI value was statistically important in the craftsmen category, predicting that people with higher SEI values and thus more prestigious occupations experienced fewer layoffs. The SEI value was not significant for laborers or craftsmen.

The capital-labor ratio is negative and statistically significant across all occupations indicating that individuals were less likely to miss work if the average manufacturing establishment in that employee's county of residence was more capital intensive. In particular, operatives and craftsmen from counties with larger capital-labor ratios missed substantially fewer days than those from counties with smaller capital-labor ratios. Laborers followed the same trend but the effect was smaller than for operatives and craftsmen. If more-skilled workers also worked with more capital, it plausible that employers operating relatively more capital intensive establishments did not want equipment laying idle and were, therefore, less likely to lay off workers. This finding is consistent with Chandler's (1977) 'throughput' hypothesis. He argues that modern industrial enterprises captured economies by keeping their factories running 
continuously at close to full capacity. It follows that capital-intensive firms attempting to capture throughput economies were less likely to lay off workers.

The number of manufacturing establishments in the county was negative and statistically significant across all occupations when measuring the number of days lost. This indicates that those employed in counties with fewer manufacturing establishments were more likely to experience a period of involuntary unemployment. With the evidence at hand, we cannot directly test for job attachment, but this suggests that workers expected to work for more than one employer each year. Finally, those working in central New Jersey experienced a 22 to 49percentage point higher risk of experiencing involuntary layoff according to the probit model; this result is confirmed in sign and significance by the tobit model. The one individual level control, number in family, is negative and significant for operatives indicating that those with larger families were less likely to be laid off. Perhaps this reflects a selection into a more stable form of employment which is arguably more important for those with larger families.

Our results are broadly consistent with the hypotheses set forth by Keyssar (1986), and others, and indicate that both the probability of experiencing involuntary layoffs and the number of days lost to such layoffs were experienced more by unskilled workers. In the next section, we test Smith's hypothesis that the jobs with more expected involuntary employment pay more, ceteris paribus.

\section{Involuntary Unemployment and Compensating Wage Differentials in New Jersey Manufacturing, 1883-1886}

As we noted earlier, few studies directly test Smith's hypothesis. Our paper contributes to this literature. Because Smith's hypothesis involves expected involuntary unemployment, we use the 
results from the analyses presented in Table 2 to create ex ante predictions of both the probability of losing any work due to inability to find work or what we call involuntary unemployment (created from the probit model) and the number of days lost due to inability to find work (from the tobit model). ${ }^{7}$ We then use these predicted values in log wage regressions to determine if workers with higher expected spells of involuntary unemployment were compensated for them. We also compare these results using the actual days lost and a dummy variable equal to one if they actually experienced any days lost rather than the predicted probability. Finally, we also estimate a specification proposed by Fishback and Kantor (1992) designed to disentangle whether or not a worker was unemployed due to her own lack of productivity or for industry reasons. To do this, we include in the wage model a measure of the average days lost in that worker's industry and a measure of the each particular worker's deviation from the industry average.

Tables 3 and $4 \mathrm{a}$ through $4 \mathrm{c}$ report results for linear regressions with the log real hourly wage as the dependent variable. For each occupation we estimate five equations, Equation 1 measures involuntary unemployment as the predicted probabilities generated from the probit model in Table 2. The second equation includes the predicted number of days lost due to inability to find work (generated from the tobit model in Table 2) as a regressor. Equation 3 presents the specification with the industry average days lost and the individual deviations from the average. Equations 4 and 5 are the whether or not someone was actually laid off $(0 / 1)$ and the actual number of days lost. Note that the R-squared for the models for laborers and operatives are in the 33-35 percent range, commensurate with those calculated using modern data with a much richer set of controls. The R-squared for craftsmen are lower but still imply that the

\footnotetext{
${ }^{7}$ Predicted days lost from the tobit model yielded some negative values that we truncated to zero following Hatton and Williamson (1991).
} 
estimated equations explain a sizeable fraction of the variation in the data. We discuss the results by occupation below.

\section{Full Sample Estimates}

The wage regressions in the full, pooled sample of 2,153 workers, are well behaved and the coefficients are largely consistent with prior expectations. Workers with larger families earned higher salaries. A one percent increase in the size of the family increased (log) hourly wages by about 1.8 percent across all specifications. This may reflect married workers selecting more stable, higher paying jobs. On the other hand, it may reveal that employers rewarded workers with a greater probability of extended job attachment. Henry Ford had an apparent preference for 'family' men because they remained with Ford longer than unattached men, but Maloney and Whatley (1995) argue that the predominance of married men at Ford was not the result of specific company policies. Rather Ford was one of the few employers who offered married, black men a family wage. The data here are not adequate to allow for other than speculation on the underlying cause of higher wages for married men.

More skilled workers (higher SEI code) earned more than low-skilled workers, although the regressions generally fail to capture wage differentials between laborers and craftsmen, once we control for an occupation's SEI. Operatives, on the other hand, earn lower hourly wages than craftsmen. Workers employed in counties with higher capital-labor ratios earn slightly more, but the estimates are generally not statistically significant. After controlling for regional effects, workers in counties with more manufacturing establishments earn a small, but statistically significant, wage premium over those working in counties with fewer establishments. This may reflect a demand shift effect, but our reduced-form equations preclude us from disentangling the 
supply and demand effects. Finally, wages were higher in 1884 and 1885 than in either 1883 or 1886. Because the results are comparable when we consider laborers, operatives, and craftsmen in separate regressions, we will not further discuss the control variables. We will focus, instead, on the effects of anticipated involuntary unemployment on wages.

Using the results from the pooled sample reported in Table 3, we find that workers were typically compensated for anticipated bouts of unemployment, and that the results are robust to alternative specifications of anticipated unemployment. In Equation (1) we include the predicted probability of experiencing any days lost calculated from the full-sample probit estimate in Table 2. The estimate implies that for each percentage point increase in the probability of involuntary employment, log hourly wages increased by 2.3 percent. For equations (2) through (4), we facilitate interpretation and comparison across specifications by focusing on the elasticity of $\log$ hourly wages to various measures of anticipated, involuntary unemployment. In Equation (2), we include the predicted number of days missed, calculated from the corresponding tobit specification in Table 2. Evaluated at the sample means, the parameter estimate implies a wage elasticity of predicted daily unemployment of just 0.10 . In Equation (3), we include the industry average number of days lost due to involuntary unemployment. As previously discussed, the data (and worker interviews) revealed that many workers employed in the same industry experienced approximately the same number of days lost per year. If these unemployment spells were predictable over the long run (which the documentary evidence suggests), workers may have incorporated compensation for these spells into their wage demands. Equation (3) implies a wage elasticity of industry average days lost of 0.47 . According to this estimate, a 1 percent increase in the average number of days an industry closed down during a year, induced a 0.47 percent increase in log hourly wages. Finally, Equation (4) includes as a regressor the actual ex post 
number of days lost, which may or may not accurately reflect expected unemployment. The wage elasticity of actual days lost was just 0.08 , which suggests that the ex post compensation was rather small and not nearly large enough to compensate for the actual number of days lost.

Consistent with Hatton and Williamson (1991), Fishback and Kantor (1992) and Fishback (1998), we find that workers received some compensation for anticipated unemployment. Contrary to Hatton and Williamson's contention, however, we find that even industrial workers were compensated for bouts of anticipated, involuntary unemployment. Moreover, we find that workers were compensated even when expected periods of unemployment were relatively brief, averaging just 25 days. But the results also suggest that workers were less than fully compensated for periods of unemployment. The lower bound estimate suggests that workers received just 10 percent of their salary lost to anticipated unemployment in higher hourly wages. The upper bound estimate implies a more generous 47 percent. Compensation for actual days lost amounted to just 8 percent of lost wages. As a group, workers were not fully compensated for lost time, but our preferred measure of anticipated unemployment - the industry average number of days lost [Equation (3) in Table 3] - implies that the compensation was not trivial either. We now document the returns to anticipated, involuntary unemployment by worker category.

\section{Laborers}

Laborers experienced the largest wage premium for involuntary unemployment according to Equation 1 in Table 4a. For each additional percentage point increase in the probability of involuntary unemployment, wages increased by about 2.5 percent. Equations (2) through (4) also reveal that low-skilled laborers received the largest compensating wage differential for 
anticipated unemployment. Evaluated at the sample mean, Equation (2) implies a wage elasticity of an additional day of predicted unemployment (where the predicted value is calculated from parameter estimates reported in Table 2) of 0.32 . Thus, a 1 percent increase in the predicted number of days lost led to a log hourly wage increase of 0.32 percent. Although it implies that low-skilled workers were not fully compensated for recurrent bouts of expected idleness, this estimate is considerably higher than the full-sample elasticity estimate of 0.10 , which suggests that laborers did better than workers generally. Consistent with the full-sample estimate of 0.47 , the coefficient from Equation (3) implies a wage elasticity of additional days of average industry down-time for laborers of 0.42. Equation (4) implies a wage elasticity of actual days lost of just 0.14. As with the full-sample estimates, our preferred measure of anticipated unemployment suggest that low-skill laborers received a compensating differential, but it did not fully offset the loss of wage income.

\section{Operatives}

Compared to the regressions for Laborers and Craftsmen (discussed below), the estimating equations for operatives were not particularly well behaved. Many of the coefficients on the control variables are statistically insignificant or take on an unexpected sign. Neither family size nor occupational status (SEI Code) is significant. The capital-labor ratio enters with a negative sign, implying that more capital-intensive manufacturing lowered operative's wages. This makes sense if capital and operatives were substitutes in production, but job titles such as machinist, mechanic, and so forth would seem to imply a complementarity between capital and labor. The odd results, then, may be more the consequence of our inability to accurately classify some workers than to a genuinely perverse relationship. The estimated coefficient on industry average 
days lost from Equation (3) in Table $4 \mathrm{~b}$ appears to confirm this interpretation. While the estimated wage elasticities from Equations (2) and (4) are negative and, thus, illogical, the wage elasticity of industry average days lost [Equation (3)] is 0.46 , which is consistent with estimates from both the full-sample and the laborer subsample.

\section{Craftsmen}

Following Adam Smith, Hatton and Williamson (1991) contend that compensating differentials are more likely to be found in industries, such as agriculture and construction, reliant on lowskill day laborers and subject to recurrent but predictable seasonal cycles. Like Smith, they doubt the existence of substantial differentials for skilled workers or for industrial employees. Our findings, presented above, combined with the results surveyed in Fishback (1998) and recent results reported by Atack, Bateman, and Margo (2002; 2003), refute the hypothesis that industrial low- to moderate-skilled workers did not experience recurrent spells of anticipated unemployment. They did, and they received at least partial compensation for periods of forced idleness. Our results, however, suggest that skilled craftsmen working in New Jersey manufacturing establishments received virtually no compensation for anticipated unemployment.

Equation (1) in Table 4c implies that a 1 percent increase in the probability of experiencing any amount of anticipated, involuntary idleness increased the log hourly wage by 1.1 percent. This is about one-half the implied compensation implied by the full-sample (Table 3) or laborer (Table 4a) estimates. Similarly, Equation (2) implies a wage elasticity of predicted days lost of just 0.04; and Equation (4) implies a wage elasticity of actual days lost of -0.01 . Even our preferred measure of anticipated unemployment used in Equation (3) implies a small (and statistically insignificant) elasticity of 0.06 , a value several orders of magnitude smaller 
than the approximately 0.50 value found for laborers and operatives. Our results imply that skilled craftsmen received virtually no compensation for anticipated unemployment. This result is not the consequence of craftsmen not experiencing forced idleness. Indeed, the statistics reported in Table 1 show that craftsmen lost about 21.4 days each year due to an inability to find work, compared to 27.0 days for laborers and 24.2 days for operatives. Values for predicted days lost, derived from equations reported in Table 2, and industry average days lost are comparable, as well.

\section{Discussion and Conclusions}

We have presented evidence that indicates that at least for industrial laborers Adam Smith's hypothesis holds--workers with a higher expected probability of involuntary unemployment were compensated for it. The evidence for industrial operatives is equivocal, and we find no evidence that craftsmen received a compensating differential. Using our preferred measure of anticipated unemployment - industry average days lost - our estimates imply reveal that at least for laborers, the compensation was substantial but less than fully compensated workers for anticipated time lost.

Recall, at the time, there was no unemployment insurance system or welfare system and thus workers whose occupations exposed them to long spells of involuntary unemployment were not able to make up the lost income by accessing federal or state unemployment insurance funds. Thus, our results may provide a justification for state-sponsored unemployment insurance. On the other hand, unfettered labor markers may have afforded workers alternative self-insurance mechanisms. 
Further research using the New Jersey data could proceed in several directions. First, did workers have savings that they could dip into when they were unemployed? The New Jersey data does have some information on savings that we plan to exploit to determine who was likely to save and to what extent savings could be called upon in times of unemployment. Hatton and Williamson (1991) confirm with their Michigan data set that savings were important but did not completely offset the lost income brought about by involuntary unemployment.

It is also possible that other family members sought work when one was unemployed--the equivalent of the modern day added-worker hypothesis that postulates when the main breadwinner in the family loses his or her job the size of the labor force grows as other family members join the labor force to make up the shortfall in earnings. We have data on the earnings of other family members and can use that to determine the extent that these earnings might be able to offset the lost earnings. Hatton and Williamson (1991) found that in their Michigan data the earnings of other family members were not a significant source of income for unskilled laborers.

Finally, workers and their families could always cut back on their expenditures during lean times. Our data do not permit us to test if this is the case. 


\section{References}

Atack, Jeremy, Fred Bateman, and Robert A. Margo. "Part-Year Operation in NineteenthCentury American Manufacturing: Evidence from the 1870 and 1880 Censuses." Journal of Economic History 62:3 (September 2002), pp. 792-809.

Atack, Jeremy, Fred Bateman and Robert A. Margo. "Productivity in Manufacturing and the Length of the Working Day: Evidence from the 1880 Census of Manufactures." Explorations in Economic History 40: 2 (April 2003), pp. 170-194.

Brown, John C. "The Condition of England and the Standard of Living: Cotton Textiles in the Northwest, 1806-1850." Journal of Economic History 50:3 (September 1990), pp. 591614.

Chandler, Alfred D., Jr. The Visible Hand: The Managerial Revolution in American Business. Cambridge, MA: The Belknap Press of Harvard University Press, 1977.

Ehrenberg, Ronald G. and Robert S. Smith. Modern Labor Economics: Theory and Policy, $7^{\text {th }}$ edition. Reading, MA: Addison-Wesley, 2000.

Fishback, Price V. “Operations of 'Unfettered' Labor Markets: Exit and Voice in American Labor Markets at the Turn of the Century." Journal of Economic Literature 36:2 (June 1998), pp. 722-765.

Fishback, Price V. and Shawn Everett Kantor. "Square Deal' or Raw Deal? Market Compensation for Workplace Disamenities, 1884-1903." Journal of Economic History 52:4 (December 1992), pp. 826-848. 
Hatton, Timothy J. and Jeffrey G. Williamson. "Unemployment, Employment Contracts, and Compensating Wage Differentials: Michigan in the 1880s.” Journal of Economic History 51:3 (September 1991), pp. 605-632.

James, John. "Reconstructing the Pattern of American Unemployment before the First World War.” Economica 62: 247 (August 1995), pp. 291-311.

Keyssar, Alexander. Out of Work: The First Century of Unemployment in Massachusetts. Cambridge: Cambridge University Press, 1986.

Maloney, Thomas N. and Warren C. Whatley. "Making the Effort: The Contours of Racial Discrimination in Detroit's Labor Markets, 1920-1940.” Journal of Economic History 55:3 (September 1995), pp. 465-493.

Maryland. First Biennial Report of the Bureau of Industrial Statistics and Information. Baltimore: Guggenheimer, Weil \& Co. Printers, 1886.

New Jersey. Bureau of Statistics of Labor and Industries. Sixth Annual Report. Trenton: W. S. Sharp Printing Company, 1883.

New Jersey. Bureau of Statistics of Labor and Industries. Seventh Annual Report. Trenton: John L. Murphy, 1885.

New Jersey. Bureau of Statistics of Labor and Industries. Eighth Annual Report. Trenton: John L. Murphy, 1885.

Reiss, Albert J. Jr. With Otis Dudley Duncan, Paul K. Hatt, and Cecil C. North. Occupations and Social Status. New York: The Free Press, 1961.

Smith, Adam. An Inquiry into the Nature and Causes of the Wealth of Nations. Edited by C. J. Bullock. New York: P. F. Collier and Son Company, 1909. 
Williamson, Jeffrey G. "Was the Industrial Revolution Worth It? Disamenities and Death in $19^{\text {th }}$ Century British Towns.” Explorations in Economic History 19:2 (July 1982), pp. 221245.

U. S. Census Office. Ninth Census (1870). A Compendium of the Ninth Census. Washington: GPO, 1872.

U.S. Department of the Interior. Census Office. Tenth Census (1880). Statistics of the Population of the United States. Washington: GPO, 1883.

U.S. Department of the Interior. Census Office. Eleventh Census (1890). Report on Population of the United States: Part I. Washington: GPO, 1895.

U.S. Department of the Interior. Census Office. Tenth Census (1880). Report on Population of the United States: Part II. Washington: GPO, 1895. 
Table 1

Summary Statistics

Means and Standard Deviations

\begin{tabular}{|c|c|c|c|c|}
\hline Variable & Full Sample & Laborers & Operatives & Craftsmen \\
\hline Hours worked & $\begin{array}{l}9.9805 \\
(.8780)\end{array}$ & $\begin{array}{l}9.9103 \\
(.7590)\end{array}$ & $\begin{array}{c}10.0490 \\
(1.0393)\end{array}$ & $\begin{array}{l}10.2174 \\
(1.1012)\end{array}$ \\
\hline Real hourly wage & $\begin{array}{l}.2130 \\
(.1041)\end{array}$ & $\begin{array}{l}.2138 \\
(.1173)\end{array}$ & $\begin{array}{c}1990 \\
(.0665)\end{array}$ & $\begin{array}{c}.2259 \\
(.06873)\end{array}$ \\
\hline Paid daily & $\begin{array}{l}.3182 \\
(.4659)\end{array}$ & $\begin{array}{c}.2997 \\
(.4583)\end{array}$ & $\begin{array}{l}.3165 \\
(.4657)\end{array}$ & $\begin{array}{c}.4037 \\
(.4914)\end{array}$ \\
\hline Paid weekly & $\begin{array}{l}.6818 \\
(.4659\end{array}$ & $\begin{array}{c}.7003 \\
(.4583)\end{array}$ & $\begin{array}{c}.6835 \\
(.4657)\end{array}$ & $\begin{array}{c}.5963 \\
(.4914)\end{array}$ \\
\hline Total lost days & $\begin{array}{c}56.1565 \\
(46.5851)\end{array}$ & $\begin{array}{c}57.6019 \\
(45.9393)\end{array}$ & $\begin{array}{c}54.0405 \\
(52.3471)\end{array}$ & $\begin{array}{c}51.3004 \\
(42.2263)\end{array}$ \\
\hline Days lost due to inability to find work & $\begin{array}{c}25.6486 \\
(42.6739)\end{array}$ & $\begin{array}{c}26.9790 \\
(42.5371)\end{array}$ & $\begin{array}{c}24.1755 \\
(45.3426)\end{array}$ & $\begin{array}{c}21.3571 \\
(39.7712)\end{array}$ \\
\hline Predicted days lost due to inability to find work & $\begin{array}{c}9.8850 \\
(14.2039)\end{array}$ & $\begin{array}{c}11.6899 \\
(14.2673)\end{array}$ & $\begin{array}{c}9.6976 \\
(15.1991)\end{array}$ & $\begin{array}{c}8.8010 \\
(18.1119)\end{array}$ \\
\hline Days lost to sickness & $\begin{array}{c}12.5741 \\
(12.1092)\end{array}$ & $\begin{array}{c}12.2306 \\
(11.6162)\end{array}$ & $\begin{array}{c}11.7257 \\
(11.7300)\end{array}$ & $\begin{array}{c}14.9423 \\
(14.2119)\end{array}$ \\
\hline Days lost for other reasons & $\begin{array}{c}12.3708 \\
(13.0733)\end{array}$ & $\begin{array}{l}11.2577 \\
(9.6703)\end{array}$ & $\begin{array}{c}12.5500 \\
(12.7512)\end{array}$ & $\begin{array}{c}18.7593 \\
(24.8641)\end{array}$ \\
\hline Average days lost by industry & $\begin{array}{c}24.8065 \\
(13.0968)\end{array}$ & $\begin{array}{c}25.8607 \\
(13.3339)\end{array}$ & $\begin{array}{c}22.3724 \\
(12.4440)\end{array}$ & $\begin{array}{c}22.8851 \\
(12.1652)\end{array}$ \\
\hline Deviation in days lost from industry & $\begin{array}{c}-.8422 \\
(40.4223)\end{array}$ & $\begin{array}{c}-1.1183 \\
(40.1597)\end{array}$ & $\begin{array}{c}-1.8031 \\
(43.5448)\end{array}$ & $\begin{array}{c}1.5280 \\
(37.7708)\end{array}$ \\
\hline Inability to find work $=0 / 1 \quad 1=$ lost time from work & $\begin{array}{c}.4570 \\
(.4983)\end{array}$ & $\begin{array}{c}.4900 \\
(.5001)\end{array}$ & $\begin{array}{c}.4043 \\
(.4914)\end{array}$ & $\begin{array}{c}.3696 \\
(.4834)\end{array}$ \\
\hline Predicted probability of inability to find work & $\begin{array}{c}.4568 \\
(.1789)\end{array}$ & $\begin{array}{c}.4900 \\
(.1702)\end{array}$ & $\begin{array}{c}.4039 \\
(.2234)\end{array}$ & $\begin{array}{c}.3688 \\
(.2146)\end{array}$ \\
\hline $\mathrm{K} / \mathrm{L}$ ratio & $\begin{array}{c}2.7211 \\
(1.0563)\end{array}$ & & & \\
\hline Number of manufacturing establishments & $\begin{array}{c}527.3479 \\
(432.5534)\end{array}$ & & & \\
\hline SEI code & $\begin{array}{c}14.2996 \\
(10.9481)\end{array}$ & $\begin{array}{c}8.521 \\
(3.5361)\end{array}$ & $\begin{array}{c}24.25 \\
(11.2836)\end{array}$ & $\begin{array}{l}28.7919 \\
(10.962)\end{array}$ \\
\hline Number in family & $\begin{array}{c}4.6655 \\
(1.6003)\end{array}$ & $\begin{array}{c}4.7390 \\
(1.6006)\end{array}$ & $\begin{array}{c}4.5989 \\
(1.5662)\end{array}$ & $\begin{array}{c}4.4111 \\
(1.6136)\end{array}$ \\
\hline Number in family that work & $\begin{array}{c}1.7779 \\
(0.8003)\end{array}$ & $\begin{array}{c}1.817 \\
(.8251)\end{array}$ & $\begin{array}{c}1.7058 \\
(.7272)\end{array}$ & $\begin{array}{c}1.6863 \\
(.7553)\end{array}$ \\
\hline Observations & 2153 & 1455 & 376 & 322 \\
\hline
\end{tabular}


Table 2

Determinants of Unemployment

Marginal Effect Coeficient from Probit and Tobit Regressions

\begin{tabular}{|c|c|c|c|c|c|c|c|c|}
\hline & \multicolumn{2}{|c|}{ Full sample } & \multicolumn{2}{|l|}{ Laborers } & \multicolumn{2}{|l|}{ Operatives } & \multicolumn{2}{|l|}{ Craftsmen } \\
\hline & $\begin{array}{l}\text { Probit } \\
\text { missinab }\end{array}$ & $\begin{array}{l}\text { Tobit } \\
\text { indayl }\end{array}$ & $\begin{array}{l}\text { Probit } \\
\text { missinab }\end{array}$ & $\begin{array}{l}\text { Tobit } \\
\text { indayl }\end{array}$ & $\begin{array}{l}\text { Probit } \\
\text { missinab }\end{array}$ & $\begin{array}{l}\text { Tobit } \\
\text { indayl }\end{array}$ & $\begin{array}{l}\text { Probit } \\
\text { missinab }\end{array}$ & $\begin{array}{l}\text { Tobit } \\
\text { indayl }\end{array}$ \\
\hline \multirow[t]{2}{*}{ Paid weekly (dummy) } & -0.0485 & -5.3334 & -0.0761 & -6.9034 & 0.1640 & 7.7244 & -0.0659 & -12.0503 \\
\hline & $(0.0261)+$ & $(1.7888)^{* *}$ & $(0.0321)^{*}$ & $(2.2388)^{* *}$ & $(0.0640)^{*}$ & $(4.6702)+$ & $(0.0684)$ & $(3.9585)^{* *}$ \\
\hline \multirow[t]{2}{*}{ Number in family } & 0.0017 & -0.0462 & 0.0076 & 0.5375 & -0.0385 & -2.6644 & 0.0131 & -0.1542 \\
\hline & $(0.0073)$ & $(0.5038)$ & $(0.0089)$ & $(0.6239)$ & $(0.0188) *$ & $(1.2612)^{*}$ & $(0.0186)$ & $(1.0625)$ \\
\hline \multirow[t]{2}{*}{ SEI index } & -0.0035 & -0.2383 & 0.0058 & 0.1111 & -0.0012 & 0.0257 & -0.0102 & -0.4923 \\
\hline & $(0.0017)^{*}$ & $(0.1187)^{*}$ & $(0.0048)$ & $(0.3295)$ & $(0.0025)$ & $(0.1643)$ & $(0.0030)^{* *}$ & $(0.1801)^{* *}$ \\
\hline \multirow[t]{2}{*}{ Laborers } & -0.0029 & -1.5768 & & & & & & \\
\hline & $(0.0468)$ & $(3.1970)$ & & & & & & \\
\hline \multirow[t]{2}{*}{ Operatives } & -0.0356 & -3.9776 & & & & & & \\
\hline & $(0.0410)$ & $(2.8797)$ & & & & & & \\
\hline \multirow[t]{2}{*}{ Capital/labor ratio } & -0.1004 & -10.1568 & -0.0475 & -6.1301 & -0.1434 & -12.7133 & -0.1390 & -12.5210 \\
\hline & $(0.0211)^{* *}$ & $(1.4707)^{* *}$ & $(0.0282)+$ & $(1.9991)^{* *}$ & $(0.0419)^{* *}$ & $(2.7956)^{* *}$ & $(0.0673)^{*}$ & $(3.8304)^{* *}$ \\
\hline \multicolumn{2}{|c|}{ Number of manufacturing -0.0002} & -0.0152 & -0.0002 & -0.0137 & -0.0003 & -0.0233 & -0.0001 & -0.0140 \\
\hline establishments & $(0.0000)^{* *}$ & $(0.0023) * *$ & $(0.0000)^{* *}$ & $*(0.0028)^{* *}$ & $(0.0001)^{* *}$ & $(0.0071)^{* *}$ & $(0.0001)$ & $(0.0043)^{* *}$ \\
\hline \multirow[t]{2}{*}{ Northwestern New Jerse } & 0.1746 & 22.8713 & 0.0232 & 11.9856 & 0.4163 & 39.8848 & 0.1819 & 17.5634 \\
\hline & $(0.0597)^{* *}$ & $(4.2366)^{* *}$ & $(0.0829)$ & $(5.9039)^{*}$ & $(0.0977)^{* *}$ & $(7.1184)^{* *}$ & $(0.2219)$ & $(11.8996)$ \\
\hline \multirow[t]{2}{*}{ Central New Jersey } & 0.3263 & 22.8600 & 0.2204 & 13.0498 & 0.3458 & 20.5875 & 0.4896 & 40.4112 \\
\hline & $(0.0371)^{* *}$ & $(2.9219)^{* *}$ & $(0.0505)^{* *}$ & $(3.8551)^{* *}$ & $=(0.0908) * *$ & $(6.2144)^{* *}$ & $(0.0966)^{* *}$ & $(6.3325)^{* *}$ \\
\hline \multirow[t]{2}{*}{ Southern New Jersey } & 0.1318 & 2.8265 & 0.0780 & -0.0857 & -0.0268 & 0.4336 & 0.0004 & -4.5461 \\
\hline & $(0.0346)^{* *}$ & (2.3669) & $(0.0471)+$ & $(3.2900)$ & $(0.1003)$ & $(6.7526)$ & $(0.1043)$ & $(6.0964)$ \\
\hline \multirow[t]{2}{*}{ Year 1883} & -0.0515 & -5.1125 & -0.0874 & -6.4212 & 0.0411 & 2.2657 & -0.1058 & -10.5142 \\
\hline & $(0.0436)$ & $(2.9354)+$ & $(0.0520)+$ & $(3.5742)+$ & $(0.1138)$ & $(7.1615)$ & $(0.1187)$ & (7.7712) \\
\hline \multirow[t]{2}{*}{ Year 1884} & -0.2615 & -21.0308 & -0.2887 & -23.1451 & -0.3005 & -17.9978 & -0.1283 & -22.4386 \\
\hline & $(0.0349)^{* *}$ & ${ }^{*}(2.4861)^{* *}$ & $(0.0413)^{* *}$ & * $(3.0418)^{* *}$ & $(0.0913)^{* *}$ & $(6.5610)^{* *}$ & $(0.0996)$ & $(5.3056)^{* *}$ \\
\hline \multirow[t]{2}{*}{ Year 1885} & -0.0911 & 0.2434 & -0.1136 & 0.2809 & -0.0633 & 5.8203 & -0.0547 & -7.5653 \\
\hline & $(0.0514)+$ & $(3.5636)$ & $(0.0630)+$ & $(4.4394)$ & $(0.1260)$ & $(8.3035)$ & $(0.1325)$ & (7.6014) \\
\hline \multirow{2}{*}{$\begin{array}{l}\text { Missing observation for } \\
\text { number In family }\end{array}$} & 0.0665 & 4.6969 & 0.0608 & 3.6137 & 0.1034 & 6.8092 & 0.0329 & 4.1420 \\
\hline & $(0.0351)+$ & $(2.4217)+$ & $(0.0419)$ & (2.9803) & $(0.0926)$ & $(5.9320)$ & $(0.0918)$ & (5.0406) \\
\hline \multirow[t]{2}{*}{ Constant } & & 42.9899 & & 30.5167 & & 37.3739 & & 63.5233 \\
\hline & & $(6.2095)^{* *}$ & & $(6.6243)^{* *}$ & & $(13.1735)^{*}$ & & $(13.3458)^{* *}$ \\
\hline Observations & 2153 & 2153 & 1455 & 1455 & 376 & 376 & 322 & 322 \\
\hline
\end{tabular}

Standard errors in parentheses

+ significant at $10 \%$; ${ }^{*}$ significant at $5 \%$; $*$ significant at $1 \%$ 
Table 3

$\ln$ (wage) Regression Models 1 - 5

FULL SAMPLE

\begin{tabular}{|c|c|c|c|c|c|}
\hline & $\begin{array}{l}\text { (1) } \\
\text { lnwage }\end{array}$ & $\begin{array}{l}(2) \\
\text { lnwage }\end{array}$ & $\begin{array}{l}\text { (3) } \\
\text { lnwage }\end{array}$ & $\begin{array}{l}\text { (4) } \\
\text { lnwage }\end{array}$ & $\begin{array}{l}\text { (5) } \\
\text { lnwage }\end{array}$ \\
\hline Number in family & $\begin{array}{l}0.0178 \\
(0.0055)^{* *}\end{array}$ & $\begin{array}{l}0.0191 \\
(0.0055)^{* *}\end{array}$ & $\begin{array}{l}0.0179 \\
(0.0055)^{* *}\end{array}$ & $\begin{array}{l}0.0190 \\
(0.0055)^{* *}\end{array}$ & $\begin{array}{l}0.0187 \\
(0.0055)^{* *}\end{array}$ \\
\hline SEI index & $\begin{array}{l}0.0154 \\
(0.0017)^{* *}\end{array}$ & $\begin{array}{l}0.0090 \\
(0.0013)^{* *}\end{array}$ & $\begin{array}{l}0.0094 \\
(0.0013)^{* *}\end{array}$ & $\begin{array}{l}0.0089 \\
(0.0013)^{* *}\end{array}$ & $\begin{array}{l}0.0091 \\
(0.0013)^{* *}\end{array}$ \\
\hline Laborers & $\begin{array}{l}0.0212 \\
(0.0358)\end{array}$ & $\begin{array}{l}0.0158 \\
(0.0360)\end{array}$ & $\begin{array}{l}0.0228 \\
(0.0358)\end{array}$ & $\begin{array}{l}0.0191 \\
(0.0360)\end{array}$ & $\begin{array}{l}0.0180 \\
(0.0359)\end{array}$ \\
\hline Operatives & $\begin{array}{l}0.0132 \\
(0.0342)\end{array}$ & $\begin{array}{l}-0.0614 \\
(0.0317)+\end{array}$ & $\begin{array}{l}-0.0566 \\
(0.0313)+\end{array}$ & $\begin{array}{l}-0.0660 \\
(0.0314)^{*}\end{array}$ & $\begin{array}{l}-0.0664 \\
(0.0313)^{*}\end{array}$ \\
\hline Capital/labor ratio & $\begin{array}{l}0.1955 \\
(0.0379)^{* *}\end{array}$ & $\begin{array}{l}0.0072 \\
(0.0177)\end{array}$ & $\begin{array}{l}0.0105 \\
(0.0166)\end{array}$ & $\begin{array}{l}0.0026 \\
(0.0166)\end{array}$ & $\begin{array}{l}0.0024 \\
(0.0165)\end{array}$ \\
\hline Number of manufacturing establishments & $\begin{array}{l}0.0005 \\
(0.0001)^{* *}\end{array}$ & $\begin{array}{l}0.0002 \\
(0.0000)^{* *}\end{array}$ & $\begin{array}{l}0.0002 \\
(0.0000)^{* *}\end{array}$ & $\begin{array}{l}0.0002 \\
(0.0000)^{* *}\end{array}$ & $\begin{array}{l}0.0002 \\
(0.0000)^{* *}\end{array}$ \\
\hline Northwestern New Jersey & $\begin{array}{l}-0.3733 \\
(0.0774)^{* *}\end{array}$ & $\begin{array}{l}-0.0422 \\
(0.0500)\end{array}$ & $\begin{array}{l}-0.0215 \\
(0.0479)\end{array}$ & $\begin{array}{l}-0.0309 \\
(0.0481)\end{array}$ & $\begin{array}{l}-0.0283 \\
(0.0478)\end{array}$ \\
\hline Central New Jersey & $\begin{array}{l}-0.6105 \\
(0.1229)^{* *}\end{array}$ & $\begin{array}{l}0.0605 \\
(0.0351)+\end{array}$ & $\begin{array}{l}0.0832 \\
(0.0326)^{*}\end{array}$ & $\begin{array}{l}0.0772 \\
(0.0328)^{*}\end{array}$ & $\begin{array}{l}0.0599 \\
(0.0331)+\end{array}$ \\
\hline Southern New Jersey & $\begin{array}{l}0.0649 \\
(0.0555)\end{array}$ & $\begin{array}{l}0.3498 \\
(0.0272)^{* *}\end{array}$ & $\begin{array}{l}0.3652 \\
(0.0272)^{* *}\end{array}$ & $\begin{array}{l}0.3524 \\
(0.0272)^{* *}\end{array}$ & $\begin{array}{l}0.3392 \\
(0.0272)^{* *}\end{array}$ \\
\hline Year 1883 & $\begin{array}{l}0.0789 \\
(0.0345)^{*}\end{array}$ & $\begin{array}{l}0.0229 \\
(0.0332)\end{array}$ & $\begin{array}{l}0.0280 \\
(0.0328)\end{array}$ & $\begin{array}{l}0.0182 \\
(0.0329)\end{array}$ & $\begin{array}{l}0.0171 \\
(0.0328)\end{array}$ \\
\hline Year 1884 & $\begin{array}{l}0.5674 \\
(0.0982)^{* *}\end{array}$ & $\begin{array}{l}0.0461 \\
(0.0325)\end{array}$ & $\begin{array}{l}0.0371 \\
(0.0283)\end{array}$ & $\begin{array}{l}0.0299 \\
(0.0284)\end{array}$ & $\begin{array}{l}0.0346 \\
(0.0283)\end{array}$ \\
\hline Year 1885 & $\begin{array}{l}0.5175 \\
(0.0476)^{* *}\end{array}$ & $\begin{array}{l}0.3445 \\
(0.0418)^{* *}\end{array}$ & $\begin{array}{l}0.3567 \\
(0.0401)^{* *}\end{array}$ & $\begin{array}{l}0.3602 \\
(0.0403)^{* *}\end{array}$ & $\begin{array}{l}0.3708 \\
(0.0401)^{* *}\end{array}$ \\
\hline Missing observation for number in family & $\begin{array}{l}-0.4923 \\
(0.0342)^{* *}\end{array}$ & $\begin{array}{l}-0.3699 \\
(0.0270)^{* *}\end{array}$ & $\begin{array}{l}-0.3725 \\
(0.0268)^{* *}\end{array}$ & $\begin{array}{l}-0.3690 \\
(0.0269)^{* *}\end{array}$ & $\begin{array}{l}-0.3711 \\
(0.0269)^{* *}\end{array}$ \\
\hline $\begin{array}{l}\text { Predicted probability of layoff } \\
\text { (one or more days) }\end{array}$ & $\begin{array}{l}2.3274 \\
(0.3968)^{* *}\end{array}$ & & & & \\
\hline Predicted number of days laid off & & $\begin{array}{l}0.0021 \\
(0.0011)+\end{array}$ & & & \\
\hline Deviation from the industry average & & & $\begin{array}{l}-0.0004 \\
(0.0002)^{*}\end{array}$ & & \\
\hline Probability of layoff & & & & & $\begin{array}{l}0.0818 \\
(0.0185)^{* *}\end{array}$ \\
\hline Days laid off & & & & $\begin{array}{l}0.0007 \\
(0.0002)^{* *}\end{array}$ & \\
\hline Industry average days laid off & & & $\begin{array}{l}0.0040 \\
(0.0007)^{* *}\end{array}$ & & \\
\hline Constant & $\begin{array}{l}-3.9154 \\
(0.3384)^{* *}\end{array}$ & $\begin{array}{l}-2.0425 \\
(0.0775)^{* *}\end{array}$ & $\begin{array}{l}-2.1501 \\
(0.0739)^{* *}\end{array}$ & $\begin{array}{l}-2.0194 \\
(0.0689)^{* *}\end{array}$ & $\begin{array}{l}-2.0380 \\
(0.0687)^{* *}\end{array}$ \\
\hline Observations & 2153 & 2153 & 2153 & 2153 & 2153 \\
\hline R-squared & 0.24 & 0.23 & 0.24 & 0.23 & 0.23 \\
\hline
\end{tabular}


Table 4a

$\ln$ (wage) Regression Models 1 - 5

LABORERS

\begin{tabular}{|c|c|c|c|c|c|}
\hline & $\begin{array}{l}\text { (1) } \\
\text { lnwage }\end{array}$ & $\begin{array}{l}(2) \\
\text { lnwage }\end{array}$ & $\begin{array}{l}\text { (3) } \\
\text { lnwage }\end{array}$ & $\begin{array}{l}\text { (4) } \\
\text { lnwage }\end{array}$ & $\begin{array}{l}\text { (5) } \\
\text { lnwage }\end{array}$ \\
\hline Number in family & $\begin{array}{l}0.0063 \\
(0.0071)\end{array}$ & $\begin{array}{l}0.0173 \\
(0.0069)^{*}\end{array}$ & $\begin{array}{l}0.0184 \\
(0.0069)^{* *}\end{array}$ & $\begin{array}{l}0.0192 \\
(0.0069)^{* *}\end{array}$ & $\begin{array}{l}0.0190 \\
(0.0069)^{* *}\end{array}$ \\
\hline SEI index & $\begin{array}{l}0.0330 \\
(0.0042)^{* *}\end{array}$ & $\begin{array}{l}0.0457 \\
(0.0038)^{* *}\end{array}$ & $\begin{array}{l}0.0470 \\
*(0.0037)^{* *}\end{array}$ & $\begin{array}{l}0.0475 \\
(0.0037)^{* *}\end{array}$ & $\begin{array}{l}0.0468 \\
(0.0037)^{* *}\end{array}$ \\
\hline Capital/labor ratio & $\begin{array}{l}0.1035 \\
(0.0260)^{* *}\end{array}$ & $\begin{array}{l}0.0353 \\
(0.0236)\end{array}$ & $\begin{array}{l}0.0176 \\
(0.0224)\end{array}$ & $\begin{array}{l}0.0170 \\
(0.0224)\end{array}$ & $\begin{array}{l}0.0122 \\
(0.0224)\end{array}$ \\
\hline Number of manufacturing establishments & $\begin{array}{l}0.0004 \\
(0.0001)^{* *}\end{array}$ & $\begin{array}{l}0.0001 \\
(0.0000)^{* *}\end{array}$ & $\begin{array}{l}0.0001 \\
(0.0000)^{* *}\end{array}$ & $\begin{array}{l}0.0001 \\
(0.0000)^{*}\end{array}$ & $\begin{array}{l}0.0001 \\
(0.0000)^{*}\end{array}$ \\
\hline Northwestern New Jersey & $\begin{array}{l}-0.1460 \\
(0.0650)^{*}\end{array}$ & $\begin{array}{l}-0.1602 \\
(0.0671)^{*}\end{array}$ & $\begin{array}{l}-0.0980 \\
(0.0667)\end{array}$ & $\begin{array}{l}-0.1297 \\
(0.0657)^{*}\end{array}$ & $\begin{array}{l}-0.1126 \\
(0.0656)+\end{array}$ \\
\hline Central New Jersey & $\begin{array}{l}-0.4956 \\
(0.0805)^{* *}\end{array}$ & $\begin{array}{l}-0.0633 \\
(0.0447)\end{array}$ & $\begin{array}{l}-0.0063 \\
(0.0438)\end{array}$ & $\begin{array}{l}-0.0274 \\
(0.0431)\end{array}$ & $\begin{array}{l}-0.0382 \\
(0.0433)\end{array}$ \\
\hline Southern New Jersey & $\begin{array}{l}-0.0022 \\
(0.0457)\end{array}$ & $\begin{array}{l}0.1915 \\
(0.0376)^{* *}\end{array}$ & $\begin{array}{l}0.2124 \\
(0.0385)^{* *}\end{array}$ & $\begin{array}{l}0.1890 \\
(0.0375)^{* *}\end{array}$ & $\begin{array}{l}0.1771 \\
(0.0375)^{* *}\end{array}$ \\
\hline Year 1883 & $\begin{array}{l}0.1824 \\
(0.0422)^{* *}\end{array}$ & $\begin{array}{l}0.1033 \\
(0.0406)^{*}\end{array}$ & $\begin{array}{l}0.0793 \\
(0.0394)^{*}\end{array}$ & $\begin{array}{l}0.0748 \\
(0.0395)+\end{array}$ & $\begin{array}{l}0.0743 \\
(0.0395)+\end{array}$ \\
\hline Year 1884 & $\begin{array}{l}0.7271 \\
(0.0993)^{* *}\end{array}$ & $\begin{array}{l}0.1825 \\
(0.0453)^{* *}\end{array}$ & $\begin{array}{l}0.1068 \\
(0.0349)^{* *}\end{array}$ & $\begin{array}{l}0.1056 \\
(0.0350)^{* *}\end{array}$ & $\begin{array}{l}0.1027 \\
(0.0350)^{* *}\end{array}$ \\
\hline Year 1885 & $\begin{array}{l}0.6087 \\
(0.0549)^{* *}\end{array}$ & $\begin{array}{l}0.3775 \\
(0.0520)^{* *}\end{array}$ & $\begin{array}{l}0.4172 \\
(0.0494)^{* *}\end{array}$ & $\begin{array}{l}0.4231 \\
(0.0494)^{* *}\end{array}$ & $\begin{array}{l}0.4396 \\
(0.0494)^{* *}\end{array}$ \\
\hline Missing observation for number in family & $\begin{array}{l}-0.5240 \\
(0.0363)^{* *}\end{array}$ & $\begin{array}{l}-0.4176 \\
(0.0329)^{* *}\end{array}$ & $\begin{array}{l}-0.4138 \\
(0.0327)^{* *}\end{array}$ & $\begin{array}{l}-0.4129 \\
(0.0328)^{* *}\end{array}$ & $\begin{array}{l}-0.4146 \\
(0.0328)^{* *}\end{array}$ \\
\hline $\begin{array}{l}\text { Predicted probability of layoff } \\
\text { (one or more days) }\end{array}$ & $\begin{array}{l}2.4572 \\
(0.3545)^{* *}\end{array}$ & & & & \\
\hline Predicted number of days laid off & & $\begin{array}{l}0.0057 \\
(0.0017)^{* *}\end{array}$ & & & \\
\hline Deviation from the industry average & & & $\begin{array}{l}-0.0009 \\
(0.0003)^{* *}\end{array}$ & & \\
\hline Probability of layoff & & & & & $\begin{array}{l}0.0840 \\
(0.0227)^{* *}\end{array}$ \\
\hline Days laid off & & & & $\begin{array}{l}0.0011 \\
(0.0003)^{* *}\end{array}$ & \\
\hline Industry average days laid off & & & $\begin{array}{l}0.0034 \\
(0.0009)^{* *}\end{array}$ & & \\
\hline Constant & $\begin{array}{l}-3.8950 \\
(02494) * *\end{array}$ & $\begin{array}{l}-2.4099 \\
(0.866) * *\end{array}$ & $\begin{array}{l}-2.3809 \\
*(0.0784) * *\end{array}$ & $\begin{array}{l}-2.3003 \\
(0.721)^{* *}\end{array}$ & -2.2919 \\
\hline Observations & 1455 & 1455 & 1455 & 1455 & 1455 \\
\hline R-squared & 0.34 & 0.33 & 0.33 & 0.33 & 0.33 \\
\hline
\end{tabular}


Table $4 b$

$\ln$ (wage) Regression Models 1 - 5

OPERATIVES

\begin{tabular}{|c|c|c|c|c|c|}
\hline & $\begin{array}{l}\text { (1) } \\
\text { lnwage }\end{array}$ & $\begin{array}{l}(2) \\
\text { lnwage }\end{array}$ & $\begin{array}{l}(3) \\
\text { lnwage }\end{array}$ & $\begin{array}{l}(4) \\
\text { lnwage }\end{array}$ & $\begin{array}{l}(5) \\
\text { lnwage }\end{array}$ \\
\hline Number in family & $\begin{array}{l}0.0015 \\
(0.0120)\end{array}$ & $\begin{array}{l}0.0066 \\
(0.0102)\end{array}$ & $\begin{array}{l}0.0092 \\
(0.0099)\end{array}$ & $\begin{array}{l}0.0099 \\
(0.0101)\end{array}$ & $\begin{array}{l}0.0111 \\
(0.0101)\end{array}$ \\
\hline SEI index & $\begin{array}{l}0.0016 \\
(0.0015)\end{array}$ & $\begin{array}{l}0.0022 \\
(0.0014)\end{array}$ & $\begin{array}{l}0.0025 \\
(0.0014)+\end{array}$ & $\begin{array}{l}0.0022 \\
(0.0014)\end{array}$ & $\begin{array}{l}0.0022 \\
(0.0014)\end{array}$ \\
\hline Capital/labor ratio & $\begin{array}{l}-0.0913 \\
(0.0447)^{*}\end{array}$ & $\begin{array}{l}-0.0617 \\
(0.0260)^{*}\end{array}$ & $\begin{array}{l}-0.0168 \\
(0.0244)\end{array}$ & $\begin{array}{l}-0.0431 \\
(0.0235)+\end{array}$ & $\begin{array}{l}-0.0350 \\
(0.0235)\end{array}$ \\
\hline Number of manufacturing establishments & $\begin{array}{l}0.0002 \\
(0.0001)^{* * *}\end{array}$ & $\begin{array}{l}0.0003 \\
(0.0001)^{* *}\end{array}$ & $\begin{array}{l}0.0003 \\
(0.0000)^{* *}\end{array}$ & $\begin{array}{l}0.0003 \\
(0.0000)^{* *}\end{array}$ & $\begin{array}{l}0.0003 \\
(0.0000)^{* *}\end{array}$ \\
\hline Northwestern New Jersey & $\begin{array}{l}0.3143 \\
(0.1163)^{* *}\end{array}$ & $\begin{array}{l}0.2217 \\
(0.0657)^{*}\end{array}$ & $\begin{array}{l}0.1148 \\
(0.0646)+\end{array}$ & $\begin{array}{l}0.1861 \\
(0.0621)^{* *}\end{array}$ & $\begin{array}{l}0.1694 \\
(0.0628)^{* *}\end{array}$ \\
\hline Central New Jersey & $\begin{array}{l}0.3048 \\
(0.1053)^{* *}\end{array}$ & $\begin{array}{l}0.2009 \\
(0.0549)^{* *}\end{array}$ & $\begin{array}{l}0.1225 \\
(0.0550)^{*}\end{array}$ & $\begin{array}{l}0.1768 \\
(0.0534)^{* *}\end{array}$ & $\begin{array}{l}0.1719 \\
(0.0550)^{* *}\end{array}$ \\
\hline Southern New Jersey & $\begin{array}{l}0.0201 \\
(0.0598)\end{array}$ & $\begin{array}{l}0.0016 \\
(0.0599)\end{array}$ & $\begin{array}{l}-0.0333 \\
(0.0607)\end{array}$ & $\begin{array}{l}0.0175 \\
(0.0597)\end{array}$ & $\begin{array}{l}0.0160 \\
(0.0599)\end{array}$ \\
\hline Year 1883 & $\begin{array}{l}-0.1546 \\
(0.0651)^{*}\end{array}$ & $\begin{array}{l}-0.1501 \\
(0.0650)^{*}\end{array}$ & $\begin{array}{l}-0.1289 \\
(0.0647)^{*}\end{array}$ & $\begin{array}{l}-0.1561 \\
(0.0651)^{*}\end{array}$ & $\begin{array}{l}-0.1555 \\
(0.0653)^{*}\end{array}$ \\
\hline Year 1884 & $\begin{array}{l}-0.1860 \\
(0.0949)+\end{array}$ & $\begin{array}{l}-0.0902 \\
(0.0559)\end{array}$ & $\begin{array}{l}-0.0536 \\
(0.0555)\end{array}$ & $\begin{array}{l}-0.0811 \\
(0.0557)\end{array}$ & $\begin{array}{l}-0.0733 \\
(0.0567)\end{array}$ \\
\hline Year 1885 & $\begin{array}{l}0.2203 \\
(0.0775)^{* *}\end{array}$ & $\begin{array}{l}0.3124 \\
(0.0800)^{*}\end{array}$ & $\begin{array}{l}0.2881 \\
(0.0743)^{* *}\end{array}$ & $\begin{array}{l}0.2586 \\
(0.0749) * *\end{array}$ & $\begin{array}{l}0.2507 \\
(0.0749) * *\end{array}$ \\
\hline Missing observation for number in family & $\begin{array}{l}-0.2386 \\
(0.0570)^{* *}\end{array}$ & $\begin{array}{l}-0.2536 \\
(0.0521)^{*}\end{array}$ & $\begin{array}{l}-0.3037 \\
(0.0516)^{* *}\end{array}$ & $\begin{array}{l}-0.2705 \\
(0.0514)^{* *}\end{array}$ & $\begin{array}{l}-0.2748 \\
(0.0516)^{* *}\end{array}$ \\
\hline $\begin{array}{l}\text { Predicted probability of layoff } \\
\text { (one or more days) }\end{array}$ & $\begin{array}{l}-0.3633 \\
(0.2485)\end{array}$ & & & & \\
\hline Predicted number of days laid off & & $\begin{array}{l}-0.0038 \\
(0.0018) *\end{array}$ & & & \\
\hline Deviation from the industry average & & & $\begin{array}{l}0.0008 \\
(0.0004)^{*}\end{array}$ & & \\
\hline Probability of layoff & & & & & $\begin{array}{l}0.0006 \\
(0.0347)\end{array}$ \\
\hline Days laid off & & & & $\begin{array}{l}-0.0006 \\
(0.0004)\end{array}$ & \\
\hline Industry average days laid off & & & $\begin{array}{l}0.0041 \\
(0.0014)^{* *}\end{array}$ & & \\
\hline Constant & -1.4178 & -1.6822 & -1.9277 & -1.7632 & -1.8036 \\
\hline & $(0.2829)^{* *}$ & $(0.1175)^{* *}$ & * $(0.1154)^{* *}$ & $(0.1063)^{* *}$ & $(0.1095)^{* *}$ \\
\hline Observations & 376 & 376 & 376 & 376 & 376 \\
\hline R-squared & 0.26 & 0.27 & 0.29 & 0.26 & 0.26 \\
\hline
\end{tabular}


Table 4c

$\ln$ (wage) Regression Models 1 - 5

CRAFTSMEN

\begin{tabular}{|c|c|c|c|c|c|}
\hline & $\begin{array}{l}\text { (1) } \\
\text { lnwage }\end{array}$ & $\begin{array}{l}\text { (2) } \\
\text { lnwage }\end{array}$ & $\begin{array}{l}\text { (3) } \\
\text { lnwage }\end{array}$ & $\begin{array}{l}\text { (4) } \\
\text { lnwage }\end{array}$ & $\begin{array}{l}\text { (5) } \\
\text { lnwage }\end{array}$ \\
\hline Number in family & $\begin{array}{l}0.0008 \\
(0.0120)\end{array}$ & $\begin{array}{l}0.0113 \\
(0.0112)\end{array}$ & $\begin{array}{l}0.0104 \\
(0.0113)\end{array}$ & $\begin{array}{l}0.0109 \\
(0.0112)\end{array}$ & $\begin{array}{l}0.0109 \\
(0.0112)\end{array}$ \\
\hline SEI index & $\begin{array}{l}0.0090 \\
(0.0045)^{*}\end{array}$ & $\begin{array}{l}-0.0003 \\
(0.0017)\end{array}$ & $\begin{array}{l}-0.0004 \\
(0.0018)\end{array}$ & $\begin{array}{l}-0.0006 \\
(0.0017)\end{array}$ & $\begin{array}{l}-0.0005 \\
(0.0017)\end{array}$ \\
\hline Capital/labor ratio & $\begin{array}{l}0.0934 \\
(0.0697)\end{array}$ & $\begin{array}{l}-0.0248 \\
(0.0444)\end{array}$ & $\begin{array}{l}-0.0351 \\
(0.0429)\end{array}$ & $\begin{array}{l}-0.0361 \\
(0.0428)\end{array}$ & $\begin{array}{l}-0.0333 \\
(0.0424)\end{array}$ \\
\hline Number of manufacturing establishments & $\begin{array}{l}0.0003 \\
(0.0001)^{* *}\end{array}$ & $\begin{array}{l}0.0002 \\
(0.0000)^{* *}\end{array}$ & $\begin{array}{l}0.0002 \\
(0.0000)^{* *}\end{array}$ & $\begin{array}{l}0.0002 \\
(0.0000)^{* *}\end{array}$ & $\begin{array}{l}0.0002 \\
(0.0000)^{* *}\end{array}$ \\
\hline Northwestern New Jersey & $\begin{array}{l}-0.1575 \\
(0.1534)\end{array}$ & $\begin{array}{l}0.0101 \\
(0.1342)\end{array}$ & $\begin{array}{l}0.0382 \\
(0.1308)\end{array}$ & $\begin{array}{l}0.0359 \\
(0.1306)\end{array}$ & $\begin{array}{l}0.0315 \\
(0.1301)\end{array}$ \\
\hline Central New Jersey & $\begin{array}{l}-0.4225 \\
(0.2270)+\end{array}$ & $\begin{array}{l}0.0466 \\
(0.0789)\end{array}$ & $\begin{array}{l}0.0745 \\
(0.0698)\end{array}$ & $\begin{array}{l}0.0760 \\
(0.0697)\end{array}$ & $\begin{array}{l}0.0696 \\
(0.0708)\end{array}$ \\
\hline Southern New Jersey & $\begin{array}{l}0.0209 \\
(0.0672)\end{array}$ & $\begin{array}{l}0.0179 \\
(0.0692)\end{array}$ & $\begin{array}{l}0.0070 \\
(0.0681)\end{array}$ & $\begin{array}{l}0.0056 \\
(0.0680)\end{array}$ & $\begin{array}{l}0.0076 \\
(0.0675)\end{array}$ \\
\hline Year 1883 & $\begin{array}{l}-0.1294 \\
(0.0900)\end{array}$ & $\begin{array}{l}-0.2061 \\
(0.0843)^{*}\end{array}$ & $\begin{array}{l}-0.2212 \\
(0.0819)^{* *}\end{array}$ & $\begin{array}{l}-0.2236 \\
(0.0817)^{* *}\end{array}$ & $\begin{array}{l}-0.2207 \\
(0.0812)^{* *}\end{array}$ \\
\hline Year 1884 & $\begin{array}{l}-0.1055 \\
(0.0715)\end{array}$ & $\begin{array}{l}-0.1842 \\
(0.0647)^{* *}\end{array}$ & $\begin{array}{l}-0.2061 \\
(0.0594)^{* *}\end{array}$ & $\begin{array}{l}-0.2073 \\
(0.0592)^{* *}\end{array}$ & $\begin{array}{l}-0.2034 \\
(0.0576)^{* *}\end{array}$ \\
\hline Year 1885 & $\begin{array}{l}0.0760 \\
(0.0870)\end{array}$ & $\begin{array}{l}0.0497 \\
(0.0870)\end{array}$ & $\begin{array}{l}0.0380 \\
(0.0871)\end{array}$ & $\begin{array}{l}0.0419 \\
(0.0866)\end{array}$ & $\begin{array}{l}0.0434 \\
(0.0865)\end{array}$ \\
\hline Missing observation for number in family & $\begin{array}{l}-0.2307 \\
(0.0575)^{* *}\end{array}$ & $\begin{array}{l}-0.1971 \\
(0.0560)^{* *}\end{array}$ & $\begin{array}{l}-0.1957 \\
(0.0562)^{* *}\end{array}$ & $\begin{array}{l}-0.1968 \\
(0.0561)^{* *}\end{array}$ & $\begin{array}{l}-0.1975 \\
(0.0561)^{* *}\end{array}$ \\
\hline $\begin{array}{l}\text { Predicted probability of layoff } \\
\text { (one or more days) }\end{array}$ & $\begin{array}{l}1.1201 \\
(0.4897)^{*}\end{array}$ & & & & \\
\hline Predicted number of days laid off & & $\begin{array}{l}0.0010 \\
(0.0014)\end{array}$ & & & \\
\hline Deviation from the industry average & & & $\begin{array}{l}0.0002 \\
(0.0005)\end{array}$ & & \\
\hline Probability of layoff & & & & & $\begin{array}{l}0.0075 \\
(0.0403)\end{array}$ \\
\hline Days laid off & & & & $\begin{array}{l}-0.0001 \\
(0.0005)\end{array}$ & \\
\hline Industry average days laid off & & & $\begin{array}{l}0.0007 \\
(0.0017)\end{array}$ & & \\
\hline Constant & $\begin{array}{l}-2.4375 \\
(0.4619)^{* *}\end{array}$ & $\begin{array}{l}-1.4897 \\
(0.1670)^{* *}\end{array}$ & $\begin{array}{l}-1.4469 \\
(0.1622)^{* *}\end{array}$ & $\begin{array}{l}-1.4203 \\
(0.1531)^{* *}\end{array}$ & $\begin{array}{l}-1.4394 \\
(0.1482)^{* *}\end{array}$ \\
\hline Observations & 322 & 322 & 322 & 322 & 322 \\
\hline R-squared & 0.22 & 0.21 & 0.21 & 0.21 & 0.21 \\
\hline
\end{tabular}


